\title{
Does Financial Inclusion Important in MSMEs Financing in Indonesia? Analysis Using Dimension Bank as Mediation
}

\author{
Karisa Zeisha Sahela ${ }^{1}$, Osama Isaac ${ }^{1}$, Askardiya Radmoyo Adjie $^{2}$ \& Riana Susanti ${ }^{2}$ \\ ${ }^{1}$ Management Department, Faculty of Business and Accountancy, Lincoln University College, Malaysia \\ 2 Management Department, Sekolah Tinggi Ilmu Ekonomi IPWI Jakarta, Indonesia \\ Correspondence: Karisa Zeisha Sahela, Ph.D Student, Faculty of Business and Accountancy, Management \\ Department, Lincoln University College, Malaysia.
}

Received: January 6, 2021

doi:10.5430/ijfr.v12n3p370
Accepted: February 5, 2021

Online Published: February 24, 2021

URL: https://doi.org/10.5430/ijfr.v12n3p370

\begin{abstract}
This study aims to see the role of banks as an effort to achieve financial inclusion. MSMEs have a very vital role in increasing economic growth in Indonesia, there are various types of MSMEs that are scattered throughout the region. The problem of MSMEs, in general is a problem of capital. To overcome this, there is one model, namely financial inclusion, which can encourage the financial system to be accessible to all levels of society. Financial inclusion is one way to socialize the financial sector, especially to facilitate banking services and financial access for the public. This study uses primary data and secondary data, in this study, researcher used MSMEs, as the population of the study. Total MSMEs in Jakarta is 930,620 Units. The results of the study show that all the variables are significant positive, in the efforts to finance MSMEs in Indonesia, which means that banks play an important role in channeling funds to MSMEs, so that inclusion runs well. This is in line with the Entrepreneurial finance theory which emphasizes that increasing business capital both from internal and external, followed by increased entrepreneurship and management capacity will be able to improve company performance, especially MSMEs.
\end{abstract}

Keywords: inclusive financing, financial intermediation, bank dimention, MSMEs

JEL Classification: G21, L32.

\section{Introduction}

Many people in developing countries have limited access to financial services (Shinozaki, 2012) whereas this basic fundamental is vital to strengthen financial sectors and domestic resource mobilization. Thus, it can make a sufficient contribution to social and economic development. Survey of (Bank Indonesia, 2011), indicated that the level of Indonesian households who have access to formal financial institutions is only 49 percent and the level of Indonesian society who are associated with banks is still low at only about 48 percent where banking services are still centralized in Java. Meanwhile, only $20 \%$ of Indonesian adults have accounts in formal financial institutions, in this case, banks, those are lower than Malaysia 66\%, China 64\%, India 35\%, and Philippines 25\%. Similarly, the financing of economic activities for Micro, Small and Medium Enterprises (MSMEs) is also considered not significant with the credit share at about $20 \%$ or around the range of Rp 612 trillion. It is not surprising that the Deposit to GDP ratio is still below 50\% and the Loan to GDP ratio is still around 35\%, far below average compared to countries in Asia Pacific region (Bank Indonesia, 2014).

Meanwhile, the financial sector, which is part of the country's economic supports, has an important role to play in promoting the economic activities of the poor so that they can continue to do their activities (World Bank 2010). Here, Micro, Small and Medium Enterprises (MSMEs) have an important and strategic role in national economic development (Bank Indonesia, 2015).

Some positive contributions of MSMEs cannot be underestimated, namely:

a. The backbone of national economy as it is the dominant business population (99.9\%).

b. Contribution of MSMEs to GDP is $60.34 \%$ with annual growth rate $6.4 \%$.

Not only that, but MSMEs have also helped the labor which experienced growth from 96.99 percent to 97.22 percent in the last five years. Thus, the Indonesian Chamber of Commerce and Industry assessed that MSMEs can increase 
people's income and are considered to have a strategic role in fighting poverty and unemployment.

Unfortunately, MSMEs here still face obstacles, especially in access to banking, which causes about 60-70 percent of MSMEs have not gained access or bank financing. Some obstacles faced by MSMEs are (Bank Indonesia, 2014): The coordination between stakeholders of MSME is still not integrated. Government agencies, educational institutions, financial institutions, and entrepreneurs' associations run independently.

a. Incomplete of supporting policies and regulations in the funding aspect for MSMEs.

b. There are still geographical barriers where not many banks are able to reach urban areas.

c. There are still limited facilities and infrastructure to support access to technology. Most MSMEs use technology that is still simple.

d. The operational procedures of banks are still complex, including lack of provision of simple credit services and high of bank administrative costs

e. Lack of education in understanding of finance and banking.

f. Still lack of public trust in financial institutions.

Inclusive financing is a national strategy to boost economic growth through the stability of the national financial system, especially if it is used to empower MSMEs that contribute substantially to the country. Therefore, this study aims to create the implementation model of inclusive financing for MSMEs empowerment in Indonesia to create stability of the national financial system.

From previous studies only examined the relationship between the effect of financial inclusion on MSME financing without adding intervening variables or variables that serve as mediation, and then previous studies had a limited population, namely only one city, or one district in Indonesia. Referring to previous research, this study proposes the dimension of the bank as novelty because the main issue of this research is MSMEs in Indonesia. The situation of this country indicates that the industry is still centered in Java because most businessmen think that Java Island, especially Jakarta, is a strategic location for investing and starting a business, and that Indonesia is categorized as underbanked and overbanked based on geography. This becomes interesting when this research is proven that the dimension bank can mediate the relationship between the influences of financial inclusion on public financing.

\section{Literature Review}

\subsection{Finance Theory}

Corporate companies have similarities with entrepreneurial firms in terms of the types of financial decisions taken, Kuratko (2004) argues that the theories developed to explain finance at the corporate level need to be adapted to the entrepreneurial situation, so as to explain the behavior of small companies and their entrepreneurs. Here are some important aspects of corporate finance from an entrepreneurial finance perspective (Kuratko, 2004):

a. Access to funding is still a major obstacle

b. Life cycle theory of financing

c. Information opacity (informational opacity)

d. Access to funding depends on the qualifications of the employer

e. There is no clear separation between business and personal finances

f. Issues regarding control and willingness to disclose information

\subsection{Investment Theory}

Jorgenson (1967) examines investment behavior in neoclassic theory (Neoclassic Theory). The theory explains that it is the exogenous variables that determine the firm's investment. The variable in question is sales. When sales increase, it is followed by an increase in investment, and vice versa when sales decrease, investment will also decrease. This theory states that a company's investment decisions are not influenced by its financial structure. This means that cash flow and debt are irrelevant in explaining investment decisions, because sales are the main determinant that affects investment. Furthermore, investment theory which is closely related to the context of MSMEs is the free cash flow theory. The information asymmetry that occurs between the owner / manager and the creditor. Steven Fazzari, R. Glenn Hubbard (1988) states that company investment depends on endogenous factors, namely cash flow. When the sensitivity of an investment to variations in cash flow is high, it indicates the company's constraints in financing its investment. The company's investment is positively influenced by cash flow. In addition, 
it is found that there is a greater sensitivity of investment to variations in cash flow in companies that are vulnerable to credit rationing, because of the information asymmetry in the relationship between owners and creditors (Fazzari \& Petersen, 1993).

\subsection{Capital Structure Theory}

Modern capital structure theory was initiated by Modigliani and Miller (MM). MM's proposition states that in a perfect capital market condition and without taxes, the funding decision whether it benefits debt or equity is no longer relevant or has an impact on the prosperity of company owner Franco Modigliani; Merton H. Miller (1958). In 1963 Modigliani and Miller corrected the previous opinion by stating that the existence of taxes imposed on income would cause the value of companies that owed to be higher than the value of companies that did not owe at all. The increase in company value will continue to rise in line with the increase in the debt ratio. This is due to the reduced tax burden, so that the net income which is the share of shareholders, ceteris paribus, becomes larger (Modigliani \& Miller, 1963).

\subsection{Pecking Order Theory}

Discussing company preferences in accessing alternative sources of funds. The pecking order theory is in opposition to the trade off theory which explains that there is no optimal debt to equity ratio for a company. This theory considers the cost of capital arising from the types of funding in determining the choice of the company's capital structure. This preference arises because of the asymmetric information between management and investors. Managers will prefer sources of funds that are least vulnerable to undervaluation due to asymmetric information. Companies will prioritize using retained earnings first, followed by debt following the issuance of new shares (Myers, 1984).

\subsection{Behavioral Finance Theory}

Behavioral finance is a study that studies how a person's psychological phenomenon affects their financial behavior (Ricciardi, 2008), which means that in financial matters, apart from the funds themselves, there are behavioral factors that influence financial decision making, which includes investment and funding decisions. The element of entrepreneurial behavior will play a very important role when discussing the conditions of funding and investment for MSMEs.

\subsection{Enterpreneurship Theory}

Mitter \& Kraus (2011) stated that the topic of funding for MSMEs can be studied from financial and entrepreneurial theory, which means that in studying the funding aspect, it is necessary to also examine the entrepreneurial aspect. The theory of entrepreneurship was first put forward by Schumpeter, which states that entrepreneurship is a process of innovation that produces new creation in business, be it in the creation of new products, ways, markets, inputs and organizations (Schumpeter, 1934). Entrepreneurship is a catalyst that destabilizes the economic flow so that it is able to initiate and support the development process. Entrepreneurship is a creative and innovative activity, which brings new products or services into economic activity. Schumpeter (1934) considered innovation as a tool for entrepreneurs, while entrepreneurs were seen as engines of growth. David C. McClelland (1965) states that entrepreneurship has characteristics such as the courage to face risks, the presence of energy and enthusiasm for activity, responsibility, individual, anticipation of future opportunities and organizational skills. David C. McClelland (1965) found a positive correlation between the need for success and entrepreneurial activity. People who have become entrepreneurs on average have a higher level of need to succeed than other people in general.

\subsection{Entrepreneurial Finance Theory}

This theory is a combination of financial and entrepreneurial theory. Yazdipour (2011) explains entrepreneurial finance as a theory that examines the financial side of entrepreneurship (financial side of entrepreneurship), this theory was born because corporate finance theory is not relevant for MSMEs. The assumptions inherent in modern corporate finance theory do not fully suit the conditions of small businesses. Theoretically, companies are assumed to have access to external capital markets for debt and equity, even though MSMEs do not necessarily own them. In the scope of investment analysis and valuation, MSMEs have a high degree of uncertainty in terms of prospects and expected cash flows compared to established large-scale companies. A similar condition also occurs in funding, where MSMEs lack broad access to external funding for debt and equity or equity. According to Denis (2004) states that the amount of pressure (magnitude) on the agency problem and asymmetric information faced by MSMEs is greater than that faced by large or established companies, so a different contractual solution is needed. 


\subsection{Inclusive Financing}

According to Bank Indonesia, in National Strategy for Inclusive Financing, inclusive financing is defined as the right of every individual to have access to a full range of quality financial services in a timely, convenient, informed manner and at affordable cost in full respect of his/her dignity. Financial services are provided to all segments of the society, with a particular attention to low-income poor, productive poor, migrant workers and people living in remote areas (Bank Indonesia, 2014).

An alternative definition of financial inclusion is the perception which views inclusion as a progression inculcating some elements of the hierarchy of needs with higher levels of financial inclusion achieved as more needs are fulfilled. This perception views Inclusive financing as a "hierarchy of financial needs" syndrome that starts by promoting non-cash methods of bill payment, advancing business through borrowing and fund investment (Adiandari \& Winata, 2018).

It is about the delivery of banking services such as savings, credit, insurance, payment, and pension, at an affordable cost to vast sections of the economy, especially the low-income segment or disadvantaged sectors (Ahmed, 2006) as presented in Figure 1. (Martinez, 2011) identified financial access as an important policy tool employed by the government infighting and stimulating growth given its ability to facilitate efficient allocation of productive resources, thus reducing the cost of capital. Financial inclusion is a concept that portrays the state in which all people have access to appropriate, desired financial products and services in order to manage their money effectively (Leyshon \& Thrift, 1995). Financial inclusion according to (Adunda \& Kalunda, 2012) is the process of availing an array of required financial services at fair price, at the right place, form, and time without any form of discrimination to all members of the society.

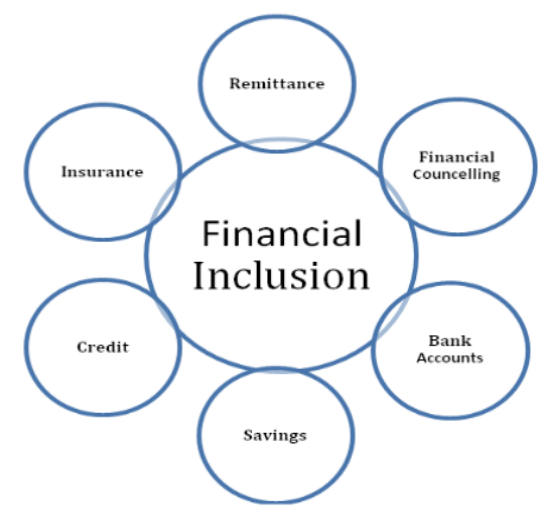

Figure 1. Essential Contents of Inclusive Financing

Source: Martinez (2011)

\subsection{Financial Intermediary Facilities and Distribution Channels}

Financial intermediary facilities and distribution channels are one of the pillars in financial inclusion issued by Bank Indonesia. Financial intermediary facilities and distribution channels aim to expand the reach of financial services to meet the needs of various community groups. This is to see the importance of financial intermediary facilities and distribution channels which emphasizes efforts to increase financial institution awareness of potential community groups to obtain financial services.

In the booklet of financial inclusion issued by (Bank Indonesia, 2014), the indicators of financial intermediary facilities and distribution channels, include:

a. Facilitating an intermediary forum by bringing together financial institutions with productive (unbanked) groups to address the asymmetric information problem.

b. Increasing cooperation between financial institutions to increase the business scale.

c. Exploring various possibilities of products, services, and innovative distribution channels while still paying attention to the principle of prudence. (Sharma Jagtap, 2019) MSME sector in emerging economies also 
presents a glaring opportunity for the banks as there is a potential for high growth in bank's Return on Equity (ROE) in MSME segment.

$\mathrm{H}_{1}=$ Financial intermediary facilities and distribution channels relate positively to MSMEs empowerment in Indonesia.

\subsection{Consumer Protection}

Consumer protection is a matter of financial institution's responsibility for losses as a result of financial institutions (Shinozaki, 2012). Consumer protection aims to provide a sense of se to the public in interacting with financial institutions and has the principles of transparency, fair treatment, reliability, confidentiality, and security of consumer data/information, handling complaints, and settling consumer disputes in a simple, fast, and affordable manner.

In the booklet of financial inclusion issued by (Bank Indonesia, 2014), the indicators of consumer protection, include:

a. Issuance of Consumer Protection Regulations for the Financial Services Sector and Payment System.

b. Establishment of Alternative Dispute Resolution Institutions as a forum for dispute resolution between consumers and financial institutions in their respective sectors that meet the principles of accessibility, independence, fairness, efficiency and effectiveness and are monitored by regulators.

c. Establishing the Internal Dispute Resolution (IDR) standard.

d. Developing the Financial Customer Care (FCC) system.

e. Provision of consultancy services and facilitation of the use of payment system products.

f. Market Conduct Activities.

$\mathrm{H}_{2}=$ Consumer protection relates positively to MSMEs empowerment in Indonesia.

\subsection{Micro, Small, Medium Enterprises (MSMEs)}

Micro, Small and Medium Enterprises (MSMEs) have different definitions in each literature according to some agencies or institutions even the law. In accordance with Act No. 20 of 2008 on Micro, Small and Medium Enterprises, MSMEs are defined as follows:

a. A micro enterprise is a productive enterprise owned by an individual and/or an individual business entity that meets the Micro Business criteria as stipulated in this Act.

b. Small-scale business is a stand-alone productive economic enterprise undertaken by an individual or a business entity that is not a subsidiary or not a branch of a company owned, controlled, or becomes part of either directly or indirectly from a Medium-Sized Enterprises or Large Business criteria for small-scale enterprises as referred to in this Act.

c. Medium-scale business is a stand-alone productive economic enterprise, conducted by an individual or a business entity which is not a subsidiary or branch of a company owned, controlled, or becomes part directly or indirectly with a Small Business or a Large Business with a net or annual sales proceeds as provided in this Act.

Statistics Indonesia (BPS) defines MSME based on labor quantity that is a home industry which has a workforce of 1 to 4 people, small business has a workforce of 5 to 19 people, while medium-sized enterprises have a workforce of 20 up to 99 people (Statistics Indonesia, 2011). In addition, based on aspects of commodities produced, MSMEs also have its own characteristics, among others:

a. The quality is not standard yet. Because most MSMEs do not yet have an adequate technological capability. The resulting product is usually in the form of handmade so that the quality standards vary.

b. The design of the product is limited. This is triggered by limited knowledge and experience about the product. The majority of MSMEs work based on order, not many who dare to try to create new designs.

c. The type of product is limited. Usually, MSMEs only produce some kind of product. If there is a demand for a new model, MSME is difficult to fulfill. Even if they received the order, it will take a long time.

d. Capacity and price list of its products is limited. With the difficulty determining the capacity and the price of the product makes the consumer difficult.

e. Less standardized raw materials. Because raw materials are obtained from different sources.

f. Continuity of the product is not guaranteed and less perfect. Because production is not regularly. 
According to Adrian (2019), one way that can be done to increase the value of exports is to improve the empowerment of products Micro, Small, Medium Enterprises. MSMEs is considered to be a solution in improving the economy in Indonesia. Furthermore, for hypotheses 3 and 4, the dimensional bank mediates the relationship between financial intermediary facilities and consumer protection distribution channels to the empowerment of MSMEs in Indonesia. While hypothesis 5 states that the bank dimension has a positive effect on the empowerment of MSMEs in Indonesia.

\section{Methodology}

In this study, the population refers to the collection of people that the study is focusing on. The main issue of this study is MSMEs in Indonesia. The country situation is indicated that the industries are still centralized in Java because most entrepreneurs choose Java, especially Jakarta, as the strategic location to invest and start business (Mardanugraha et al., 2015). Thus, this study is carried out in Jakarta. In this study, researcher used Micro, Small, Medium-Sized Enterprises as the population of the study. Owners of Micro, Small, Medium-Sized Enterprises in Jakarta is a good population to be measured because they are the main actors that know what exactly the disturbance and the obstacles in doing this business regarding problems face in inclusive financing, in which related to the purpose of the study. Based on type and source of data, researcher used primary data and secondary data which are presented.

This research is quantitative descriptive. Descriptive research is a research conducted to determine the value of each variable, whether one or more variables that are independent without making the relationship or comparison with other variables (Sujarweni, 2014). These variables can describe systematically and accurately about the population or a particular field. Quantitative research is a research that produces findings that can be achieved using statistical procedures or other quantification (measurement) (Sujarweni, 2014). In a quantitative approach, the nature of the relationship between variables is analyzed using objective theory. The method used in this research is explanatory survey method, to get data and use research instruments, for example, by distributing questionnaire, structured interviews, and so on (Sugiyono, 2013). This research will be cross-sectional study because it takes a relatively short amount of time and a certain place and is done on several objects with different levels (Sujarweni, 2014).

According to (Sujarweni, 2014), primary data is data obtained from respondents through questionnaires, focus groups, and panels or also data from researchers' interviews with resource persons. Sources that provide data directly for data collectors. While secondary data is data obtained from notes, books, magazines, corporate publications, government reports, articles, books as a theory, and so on. Sources that do not provide data directly for data collector.

In this study, researcher used Micro, Small, Medium-Sized Enterprises as the population of the study. Owners of Micro, Small, Medium-Sized Enterprises in Jakarta is a good population to be measured because they are the main actors that know what exactly the disturbance and the obstacles in doing this business regarding problems face in inclusive financing, in which related to the purpose of the study. Total Micro, Small, Medium-Sized Enterprises/MSMEs in Jakarta is 930,620 Units. In general, the research conducted does not examine all population. This is due to several factors such as the large amount of population, time and cost limitations. Therefore, researcher takes a part of the population called the sample. According to (Sugiyono, 2013), the sample is a part of the number and characteristics possessed by the population. It is important that the sample can represent the population.

Table 1. Measurement for independent variables

\begin{tabular}{lrl}
\hline Financial Intermediary Facilities and Distribution Channels \\
\hline Indicator & a. & $\begin{array}{l}\text { Facilitating an intermediary forum by bringing together financial institutions with } \\
\text { productive (banked and unbanked) groups to address the asymmetric information } \\
\text { problem. }\end{array}$ \\
\hline Question & 1) & $\begin{array}{l}\text { With a smart behavior program, we easily get information and conduct financial } \\
\text { service transactions. }\end{array}$ \\
\hline Indicator & b. & Increasing cooperation between financial institutions to increase the business scale. \\
\hline Question & 2) & $\begin{array}{l}\text { With the existence of local credit guarantee company, we easily get capital for } \\
\text { business development. }\end{array}$ \\
\hline Indicator & c. & $\begin{array}{l}\text { Exploring various possibilities of products, services, and innovative distribution } \\
\text { channels while still paying attention to the principle of prudence. }\end{array}$ \\
\hline Question & 3) & Through retail mutual funds, MSMEs can invest in the capital market \\
\hline
\end{tabular}




\begin{tabular}{lll}
\hline Consumer Protection \\
\hline Indicator & a. & $\begin{array}{l}\text { Issuance of Consumer Protection Regulations for the Financial Services Sector and } \\
\text { Payment System. }\end{array}$ \\
\hline Question & 1) & With the issuance of consumer protection regulations, consumers feel more protected \\
\hline Indicator & b. & $\begin{array}{l}\text { Establishment of Alternative Dispute Resolution Institutions as a forum for dispute } \\
\text { resolution between consumers and financial institutions in their respective sectors that } \\
\text { meet the principles of accessibility, independence, fairness, efficiency and } \\
\text { effectiveness and are monitored by the regulators. }\end{array}$ \\
\hline Question & 2) & $\begin{array}{l}\text { With the establishment of Alternative Dispute Resolution Institutions, the dispute } \\
\text { resolution between consumers and financial institutions is easier, transparent, fair, } \\
\text { effective and efficient. }\end{array}$ \\
\hline Indicator & c. & Establishing the Internal Dispute Resolution (IDR) standard. \\
\hline Question & 3) & $\begin{array}{l}\text { The Internal Dispute Resolution (IDR) standard create a balance between financial } \\
\text { service institutions and consumers. }\end{array}$ \\
\hline Indicator & d. & Developing the Financial Customer Care (FCC) system. \\
\hline Question & 4) & $\begin{array}{l}\text { The Financial Customer Care (FCC) system increase customer service to become } \\
\text { more effective, fast, and responsive. }\end{array}$ \\
\hline Indicator & e. & $\begin{array}{l}\text { Provision of consultancy services and facilitation for the use of payment system } \\
\text { products. }\end{array}$ \\
\hline Question & 5) & $\begin{array}{l}\text { With the consultancy service provider for payment system products will guarantee } \\
\text { legal certainty for consumers. }\end{array}$ \\
\hline Indicator & f. & Market Conduct Activities. \\
\hline Question & 6) & $\begin{array}{l}\text { Market intelligence activities ease to identify business practices that have the potential } \\
\text { to harm consumers. }\end{array}$ \\
\hline
\end{tabular}

Source: Bank Indonesia (2011)

Table 2. Measurement for mediation variable

\begin{tabular}{l} 
Banking Dimension \\
\hline Question 1) Financial institutions have policies, products and services specifically targeting poor \\
and marginal groups. \\
2) Financial institutions have branches not only in urban but also in rural areas. \\
3) Financial institutions provide branch office financial services, non-cash services \\
(e-money), and banking services through cellphones. \\
4) Proportion distributed by financial institution for MSMEs above 10\%. \\
5) Financial institutions do not need collateral for MSMEs loans. \\
6) Financial institutions have policies to reveal the client's rights and the risks of products \\
7) Terms and conditions of financial institutions provided to the clients in national/local \\
8) Financial institutions have policies to improve financial literacy for low-income and \\
marginal groups and MSMEs. \\
9) Financial institutions do not charge fees from the clients to open basic bank account. \\
10) Financial institutions do not regulate the minimum balances to maintain a bank \\
account. \\
11) Financial institutions have standards and provide information about credit processing \\
time. \\
12) Financial institutions have financial products which are feasible, affordable and \\
convenient to send or receive remittances from within the country through an account. \\
13) Financial institutions provide housing finance for low-income groups of people.
\end{tabular}

Source: Bank Indonesia (2011) 
Table 3. Measurement for dependent variable

\begin{tabular}{lll}
\hline \multicolumn{2}{l}{ MSMEs Empowerment } \\
\hline Indicator & a. & The amount of income earned by MSMEs. \\
\hline Question & 1) & After getting People's Business Credit, the income obtained is increasing. \\
& 2) & After getting the business assistance, it is easier for us to manage our income better. \\
\hline \multicolumn{7}{l}{} \\
\hline Questicator & b. & The number of workers owned. \\
\hline Indicator & 1) & After getting the business assistance, the number of our workers is increasing. \\
\hline Question & 1) & The amount and quality of products sold or produced. \\
& 2) & After getting the business assistance, the amount of the product produces/sold is \\
& better. \\
& 3) & After getting the business assistance, the products produced/sold is more diverse.
\end{tabular}

Source: Bank Indonesia (2011)

\section{Empirical Results and Discussion}

The evaluation of the structural model (inner model) aims to predict the relationship between variables by seeing how much the variance can be explained and knowing the significant P-value (Hair et al. 2013). Thus through the evaluation of the structural model can answer hypothesis testing in this study, namely hypotheses 1,2 and 3, 4. As for hypothesis 5 (the effect of mediation) will be tested through mediation testing in the next analysis.

Table 4. Goodnes of Fit Model Structural

\begin{tabular}{ll}
\hline Criteria & Parameter \\
\hline Average path coefficient (APC) & $0.376 / \mathrm{P}<0.001$ \\
\hline Average R-squared (ARS) & $0.746 / \mathrm{P}<0.001$ \\
\hline Average adjusted R-squared (AARS) & $0.744 / \mathrm{P}<0.001$ \\
\hline Average block VIF (AVIF) & 4.801 \\
\hline Average full collinearity VIF (AFVIF) & 3.296 \\
\hline Tenenhaus GoF (GoF) & 0.726 \\
\hline Sympson's paradox ratio (SPR) & 1.000 \\
\hline R-squared contribution ratio (RSCR) & 1.000 \\
\hline Statistical suppression ratio (SSR) & 1.000 \\
\hline
\end{tabular}

Sources: Primary data and secondary data is processed (2020)

Based on Table 4. above, it can be seen that this research model has a good fit, where the

$\mathrm{P}$ value for APC $<0.001$, ARS and AAR $<0.001$, with an APC value $=0.376$, ARS value $=0.746$ and $\mathrm{AARS}$ value $=$ 0.744. Likewise, the resulting AVIF and AFVIF values are <3.3, which means that there is no multicolonierity problem between indicators and between exogenous variables. The resulting GoF is $0.726>0.1$ which means that the fit model is very good. For SPR and RSCR it produces a value equal to 1 while SSR is with a value of $1.000>0.7$ which means there is no causality problem in the model.

In this study, the mediation test used the Variance Accounted For (VAF) method. Hair et al. (2013) According to the mediation testing procedure with the VAF method, it is as follows:

1. Testing the direct effect of exogenous variables on endogenous without including the mediating variable.

2. If the direct effect above is significant, then test the indirect effect of exogenous variables on endogenous by including the mediating variable.

3. If the indirect effect above is significant, then calculate the value of the VAF and determine the mediation effect with the following criteria: 
a. $\mathrm{VAF}>80 \%$ means that there is full mediation.

b. $20 \%<\mathrm{VAF}<80 \%$ means that there is partial mediation.

c. VAF $<20 \%$ means no mediating effect in the model. To calculate the Variance Accounted For (VAF) it is calculated by dividing the indirect effect by the total effect (direct effect plus indirect effect).

Table 5. The next step is to calculate the VAF value

\begin{tabular}{ll}
\hline Description & Path Coefisien \\
\hline Indirect effect & 0.319 \\
\hline Direct effect & 0.038 \\
\hline Total effect & 0.245 \\
\hline VAF (indirect effect/total effect) & 0.602 \\
\hline
\end{tabular}

Sources: Primary data and secondary data is processed (2020)

Based on Table 5, the results of the VAF value are 0.602 or $60,2 \%$. This value can be seen as close $20 \%<\mathrm{VAF}<80 \%$ means that there is partial mediation so that it shows BD as a partial mediator of the indirect effect of FI on BD. These results support or accept Hypothesis 3 which states that bank dimention can mediate the effect of financial intermediation on MSMEs Empowering. These findings indicate that the empowerment of MSMEs is not only influenced by financial intermediation but also customer protection, so that UMKM empowerment can run well.

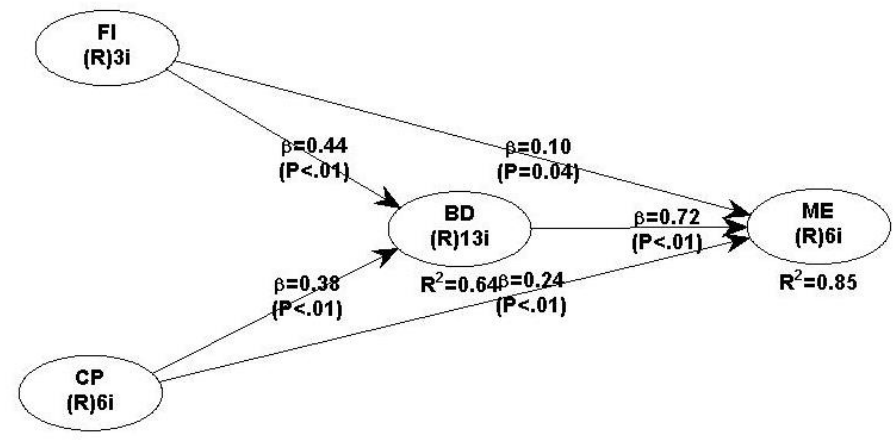

Figure 2. Full model research

Sources: Primary data and secondary data is processed (2020)

$\mathrm{H}_{1}=$ Financial intermediary facilities and distribution channels relate positively to MSMEs empowerment in Indonesia. The test results with a coefficient value of 0.10 and a p-value of 0.04 (4\%), then the first hypothesis is accepted. This result is in line with Beck \& De La Torre (2007), where funds are one of the vital resources needed to survive. Increasing access to funding both from the amount, the process of revenue funds will support the realization of opportunities previously identified along with other productive resources, banks as intermediaries also have an important role in services and funding, especially for MSMEs. Likewise with the theory of entrepreneurial finance, which theoretically assumes that companies have access to external capital markets for debt and equity, even though MSMEs do not necessarily own them. In the scope of investment analysis and valuation, MSMEs have a high degree of uncertainty in terms of prospects and expected cash flows compared to large, established companies.

$\mathrm{H}_{2}=$ Consumer protection relates positively to MSMEs empowerment in Indonesia. The test results with a coefficient value of 0.24 and a p-value of $<0.001$, then the second hypothesis is accepted. This result is in line with Guntur \& Zainal (2019) which states that protection of consumers is one of the most important things, so that the process of empowering MSMEs runs effectively. Behavioral finance theory states that how a person's psychological phenomena affect their financial behavior.

$\mathrm{H}_{3}=$ The bank dimension can mediate influence financial intermediary facilities and distribution channels relate positively to MSMEs empowerment in Indonesia. The test results with a coefficient value of 0.44 and a p-value of 
$<0.001$, the results are significant, so the third hypothesis is accepted. The test results are in line with Diah (2016). The results of the study show that commitment, communication, and support among stakeholders, namely banks play an important role in empowering MSMEs. Pecking order theory states that considering the cost of capital arising from the types of funding in determining the choice of a company's capital structure.

$\mathrm{H}_{4}=$ The bank dimension can mediate influence consumer protection relates positively to MSMEs empowerment in Indonesia. The test results with a coefficient value of 0.38 and a p-value of $<0.001$, the results are significant, so the fourth hypothesis is accepted. Faraj Aldaihani et al (2020) in their research stated that the importance of social relationship management in customer satisfaction. Entrepreneurship theory states that entrepreneurship has characteristics such as the courage to face risks, the presence of energy and enthusiasm for activity, responsibility, individual, anticipation of future opportunities and organizational skills.

$\mathrm{H}_{5}=$ Bank dimension has a positive effect on the empowerment of MSMEs in Indonesia. The test results with a coefficient value of 0.72 and a p-value of $<0.001$, the results are significant, so the fourth hypothesis is accepted. This result strengthens the findings of Ardiansyah (2016) which states that MSME entrepreneurs build partnerships with banks, where the government must establish credit guarantees to facilitate access for MSME entrepreneurs in terms of funding.

\section{Conclusion}

The principle of financial inclusion is to expand access to information technology for the public, especially umkm actors, to achieve a sound financial system (Abubakar \& Handayani, 2019). Adiandari \& Winata (2018) MSMEs is formed and materialized with a good performance if financing from banks can accelerate the financial inclusion system. The results showed that all independent variables, namely financial intermediation and customer protection, proved that in MSMEs financing the elements of the bank as intermediaries for MSMEs actors could accelerate MSMEs performance as well as customer protection, which is one of the important things in realizing financial inclusion. The results also show that the bank dimensions play an important role in mediating the relationship between the independent and dependent variables, which is either directly or indirectly proven if bank financing is optimal for the sustainability of MSMEs along with the implementation of good financial inclusion.

Inclusive financing is a national strategy to encourage economic growth through the stability of the national financial system, especially if it is used to empower MSMEs that make a large contribution to the country. Therefore, this study aims to create a model for implementing inclusive financing for the empowerment of MSMEs in Indonesia to create national financial system stability. The focus of this research is to examine the influence of the five pillars of inclusive financing on the empowerment of MSMEs and the influence of institutional conditions on the empowerment of MSMEs. The results of the implementation model are intended as a framework to support an inclusive financing strategy to encourage the economic activities of people who have not yet enjoyed access to financial services, so as to create state financial stability.

\section{Limitations and Suggestions}

1. Socialization to MSMEs about financial management strategies and

2. Capital Regular UMKM guidance

3. Regular UMKM assessment

4. Increase the number of financial products aimed at MSMEs

5. Make sure the community understands that social assistance is used for

6. the productive sector is not consumptive

7. Create non-overlapping legal protection policies,

8. for example the tax rate, then socialize it

9. Review policies that can maintain MSME resources at

10. Indonesia, for example, agrarian and maritime

\section{References}

Abubakar, L., \& Handayani, T. (2019). Strengthening financial technology regulation to empowerment financial inclusive. Diponegoro Law Review, 4(2), 274. https://doi.org/10.14710/dilrev.4.2.2019.274-290

Adiandari, A. M., \& Winata, H. (2018). Financial inclusion in Indonesia: application of MSME accelerating model to access bank financing. Review of Integrative Business and Economics, 7(1), 2304-1013. Retrieved from http://sibresearch.org/uploads/3/4/0/9/34097180/riber_7-s1_sp_s17-133_276-298.pdf 
Adrian, A. (2019). Empowerment strategies of Micro, Small, Medium Enterprises (MSMEs) to improve Indonesia export performance. International Journal of Economics, Business and Accounting Research (IJEBAR), 2(4), 50-60. https://doi.org/10.29040/ijebar.v2i04.222

Ardiansyah, M. (2016). Development models and strategy of Micro, Small and Medium Enterprises (MSMEs) in South Sulawesi. International Conference of Integrated Microfinance Management (IMM-16), 175-180. https://doi.org/10.2991/imm-16.2016.27

Bank Indonesia. (2011). Inclusive Finance Survey. Jakarta: Bank Indonesia. Retrieved October 10, 2017, from http://www.bi.go.id/id/statistik/seki/terkini/moneter/Contents/Default.aspx

Bank Indonesia. (2014). Inclusive finance booklet. Jakarta: Bank Indonesia. Retrieved October 10, 2017, from http://www.bi.go.id/id/perbankan/keuanganinklusif/edukasi/Contents/Buku\%20Saku\%20Keuangan\%20Inklusif. pdf

Beck, T., \& De La Torre, A. (2007). The basic analytics of access to financial services. Financial Markets, Institutions and Instruments, 16(2), 79-117. https://doi.org/10.1111/j.1468-0416.2007.00120.x

Diah, M. P. (2016). Implementation of Bank Indonesia CSR Program on Empowerment the Micro, Small, Medium Enterprises (MSMEs) (Study at the Artisans of Tenun Ikat Bandar Kidul, Kediri City, East Java). Public Administration Scientific Journal, 2(4), 207-215. https://doi.org/10.21776/ub.jiap.2016.002.04.13

Faraj Aldaihani, F. M., Bin Ali, N. A., Hashim, H. B., \& Basha, N. K. (2020). Impact of social customer relationship management on customer retention of Islamic banks in Kuwait: The mediating role of customer empowerment. International Journal of Supply Chain Management, 9(1), 330-337. Retrieved from http://www.ojs.excelingtech.co.uk/index.php/IJSCM/article/view/3017

Guntur, M., \& Zainal, H. (2019). Empowerment of micro business in the department of trade, industry, cooperative and small and medium enterprises. Advances in Social Science, Education and Humanities Research (ASSEHR), 227(02), 454-457. https://doi.org/10.2991/icamr-18.2019.109

Mardanugraha, E., Anastasya, A., \& Andi, M. J. (2015). Optimal financing system for Indonesian SMEs. Apen Conference on Asia-Africa Aerial and Optical silk Road Bandung, 11-12. Retrieved from https://multisite.itb.ac.id/ftsl/wp-content/uploads/sites/8/2015/12/22-4-prof.-eugenia-UI-optimal-Financing-Syst em-for-Indonesian-SMEs.pdf

Martinez, M. (2011). The polotical economy of increased financial access. Washington, D.C.: Georgetown University. Retrieved October $\quad 10, \quad 2017, \quad$ from https://repository.library.georgetown.edu/bitstream/handle/10822/553824/martinezMonicaV.pdf;sequnce=1

Schumpeter, J. A. (1934). The theory of economic development: An inquiry into profits, capital, credit, interest, and the business cycle (Vol 55). Oxford University Press. Retrieved from https://cambridgeforecast.wordpress.com/2007/12/page/7/

Sharma Jagtap, M. (2019). Banking finance innovation for msme sector in emerging Asian economies. Amity Journal of Management Amity Business School, VII(2), 52-65. Retrieved from https://www.amity.edu/gwalior/ajm/pdf/PAPER5.pdf

Shinozaki, S. (2012). A new regime of SME finance in emerging Asia: empowering growth-oriented SMEs to build resilient national economies. ADB Working Paper Series on Regional Economic Integration, 2(5), 104-153. Retrieved from http://hdl.handle.net/10419/109602\%0AStandard-Nutzungsbedingungen

Statistics Indonesia. (2011). Inclusive finance survey. Jakarta: Statistics Indonesia. Retrieved October 10, 2017, from https://jakarta.bps.go.id/index.php/publikasi

World Bank. (2010). Inclusive financing survey. Washington, D.C.: World Bank. Retrieved October 10, 2017, from https://data.worldbank.org/

\section{Copyrights}

Copyright for this article is retained by the author(s), with first publication rights granted to the journal.

This is an open-access article distributed under the terms and conditions of the Creative Commons Attribution license (http://creativecommons.org/licenses/by/4.0/). 